\title{
PENGARUH KELUARGA, ETNIS, KEPRIBADIAN, GENDER, DAN TEMAN SEBAYA TERHADAP MINAT BERWIRAUSAHA
}

\author{
Murwani Eko Astuti \\ Universitas Jenderal Achmad Yani Yogyakarta \\ murwaniastuti@gmail.com
}

\begin{abstract}
This paper investigates the factor which affected the student intention to be entrepreneur. The influences of family backround, ethnic, personality, gender and peer towards entrepreneurship are examined. Survey toward 88 students from four department in Faculty of Economics and Social, Universitas Jenderal Achmad Yani Yogyakarta (UNJAYA) were completed and regression analysis were employed to analyze the data. The result shows that personality and peer affected entrepreneur intention. Family background, ethnics, and gender are not important factor in influencing student intention to be entrepreneur as their career.
\end{abstract}

Keywords: Entrepreneurship, Family, Ethnic, Personality, Gender, Peer.

\begin{abstract}
ABSTRAK
Tujuan penelitian adalah untuk mengidentifikasi pengaruh keluarga, etnis, kepribadian, gender, dan teman sebaya terhadap minat berwirausaha mahasiswa di Fakultas Ekonomi dan Sosial Universitas Jenderal Achmad Yani Yogyakarta (FES UNJAYA). Penelitian ini menggunakan metode kuantitatif dengan survei yang dilakukan pada 88 mahasiswa dari empat prodi di FES UNJAYA. Hasil penelitian menunjukkan bahwa kepribadian dan teman sebaya berpengaruh terhadap minat berwirausaha mahasiswa FES UNJAYA sedangkan keluarga, etnis, dan gender tidak mempunyai pengaruh terhadap minat berwirausaha mahasiswa.
\end{abstract}

Kata kunci: Kewirausahaan, Keluarga, Etnis, Kepribadian, Gender, Teman Sebaya. 


\section{PENDAHULUAN}

Indonesia merupakan negara kekuatan jika mampu menggerakkan berkembang di Asia yang berpotensi roda perekonomian. Salah satu untuk menjadi salah satu negara penggerak dalam meningkatkan dengan dengan kekuatan ekonomi kinerja ekonomi adalah jumlah terbesar di dunia tahun 2045. wirausahawan. Berdasarkan data Menurut data Worldometers seperti yang dilansir dalam worldometers.info, jumlah penduduk Indonesia pada tahun 2018 sebesar 267.670.543 juta jiwa. Jumlah Badan Pusat Statistik (BPS) tahun 2018, tingkat pengangguran terbuka (TPT) sejak Februari 2017 sampai Februari 2018 naik sebesar 1,13 persen.

penduduk yang banyak bisa menjadi

Tabel 1.1 Tingkat Pengangguran Terbuka Lulusan Perguruan tahun 2016 - 2018

\begin{tabular}{|c|l|c|c|c|}
\hline \multirow{2}{*}{ No } & \multirow{2}{*}{$\begin{array}{c}\text { Pendidikan } \\
\text { tertinggi yang } \\
\text { ditamatkan }\end{array}$} & 2016 & 2017 & 2018 \\
\cline { 3 - 5 } & Februari & Februari & Februari \\
\hline 1 & Universsitas & 695.304 & 606.939 & 789.113 \\
\hline 2 & Diploma & 249.362 & 249.705 & 300.845 \\
\hline 3 & SMK & 1.348 .327 & 1.383 .022 & 1.424 .428 \\
\hline 4 & SLTA Umum & 1.546 .699 & 1.552 .894 & 1.650 .636 \\
\hline 5 & SLTP & 1.313 .815 & 1.281 .240 & 1.249 .761 \\
\hline 6 & SD & 1.218 .951 & 1.292 .234 & 967.630 \\
\hline 7 & Tidak tamat SD & 557.418 & 546.897 & 446.812 \\
\hline & $\begin{array}{l}\text { Tidakpernah } \\
8\end{array}$ & 94.293 & 92.331 & 42.039 \\
\hline
\end{tabular}

Sumber: www.bps.go.id

Meskipun tingkat pengangguran terbuka turun sejak Februari 2016 tetapi ada peningkatan pengangguran pada lulusan perguruan tinggi. Hal ini menunjukkan bahwa lulusan perguruan tinggi belum terserap di lapangan kerja yang ada di Indonesia. Menurut Bappenas seperti yang dilansir dalam www.bappenas.go.id meskipun pada tahun 2018 terdapat 2,99 juta lowongan kerja tetapi hanya 2,6 juta 
tenaga kerja yang mendapat pekerjaan dari jumlah lowongan tersebut. Kondisi ini menunjukkan bahwa ada ketidaksesuaian antara kebutuhan dengan ketersediaan tenaga kerja serta adanya kerbatasan keahlian tenaga kerja yang tersedia. Dengan demikian dibutuhkan penciptaan lapangan kerja dengan cara penambahan jumlah wirausahawan sehingga mengurangi tingkat pengangguran.

Kewirausahaan merupakan syarat kesuksesan untuk mencapai posisi perekonomian yang kokoh (Baycan, 2011). Kewirausahaan juga merupakan penggerak penting dalam kinerja perekonomian di seluruh dunia (Husna, 2010) karena mempunyai kemampuan dalam menciptakan lapangan kerja sehingga mengurangi tingkat pengangguran (Kulagasaran, 2010). Berdasarkan data Global Entrepreneurship Index tahun 2018, Indonesia menempati urutan ke sembilan puluh empat dari seratus tiga puluh tujuh negara (The Gedi, 2019). Global Entrepreneurship Index mengukur ekosistem kewirausahaan di seratus tiga puluh tujuh negara dan membuat rangking dari kinerja masing-masing negara. Berdasarkan data yang dilansir dari www.ristekdikti.go id, Kementerian Koperasi dan UKM menyatakan bahwa ada peningkatan jumlah wirausahawan dari tahun 2014 sebesar 1,6 persen menjadi 3,1 persen pada tahun 2017 dari total jumlah penduduk (ristekdikti, 2019). Pemerintah Indonesia telah mencanangkan Program Gerakan Mahasiswa Pengusaha yang bertujuan untuk menumbuhkan dan mengembangkan kewirausahaan pada mahasiswa. Hal ini bertujuan agar jumlah wirausahawan baru yang berasal dari mahasiswa bertambah sehingga ketika lulus kuliah sudah mempunyai usaha. Selain itu pemerintah juga memberikan acuan mengenai pendidikan kewirausahaan bagi mahasiswa perguruan tinggi. Hal ini menunjukkan zbahwa Pendidikan tinggi merupakan sebagai salah satu lembaga yang bertujuan membekali mahasiswa dengan sikap mental wirausaha (Badawi, 2011).

Fakultas Ekonomi dan Sosial Universitas Jenderal Achmad Yani Yogyakarta (UNJAYA) terdiri dari empat prodi yaitu Prodi Manajemen, 
Prodi Akuntansi, Prodi Hukum, dan Prodi Psikologi. Prodi Manajemen, Prodi Akuntansi serta Prodi Psikologi menyelenggarakan pendidikan kewirausahaan sebagai mata kuliah wajib. Sedangkan Prodi Hukum tidak menyelenggarakan pendidikan kewirausahaan. Prodi Manajemen dan Prodi Akuntansi telah beberapa kali mengadakan seminar tentang kewirausahaan untuk mendukung mahasiswa menjadi wirausahawan. Dalam rangka mendukung program pemerintah untuk menciptakan wirausahawan yang berasal dari mahasiswa serta memetakan faktorfaktor yang mempengaruhi minat mahasiswa untuk berwirausaha maka penelitian ini ingin mengetahui pengaruh keluarga, etnis, kepribadian, gender, dan teman sebaya terhadap minat kewirausahaan mahasiswa di lingkungan Fakultas Ekonomi dan Sosial (FES) sehingga bisa menentukan kurikulum dan pembelajaran mata kuliah kewirausahaan.

\section{Rumusan Masalah}

Berdasarkan identifikasi masalah di atas maka penelitian ini memiliki rumusan masalah sebagai berikut:

1. Bagaimana pengaruh keluarga terhadap minat berwirausaha mahasiswa FES UNJAYA?

2. Bagaimana pengaruh asal etnis mahasiswa terhadap minat berwirausaha mahasiswa FES UNJAYA?

3. Bagaimana pengaruh kepribadian mahasiswa terhadap minat berwirausaha mahasiswa FES UNJAYA?

4. Bagaimana pengaruh gender mahasiswa terhadap minat berwirausaha mahasiswa FES UNJAYA?

5. Bagaimana pengaruh teman sebaya mahasiswa terhadap minat berwirausaha mahasiswa FES UNJAYA? 


\section{Tujuan Penelitian}

Penelitian ini bertujuan untuk:

1. Mengetahui pengaruh keluarga terhadap minat berwirausaha mahasiswa FES UNJAYA

2. Mengetahui pengaruh asal etnis mahasiswa terhadap minat berwirausaha mahasiswa FES UNJAYA

3. Mengetahui pengaruh kepribadian mahasiswa terhadap minat berwirausaha mahasiswa FES UNJAYA

4. Mengetahui pengaruh gender mahasiswa terhadap minat berwirausaha mahasiswa FES UNJAYA

5. Mengetahui pengaruh teman sebaya terhadap minat berwirausaha mahasiswa FES UNJAYA

hasil survei oleh The Hartford dalam The Hartford's 2013 Small Business Success Study, wirausahawan mempunyai kepribadian dan karaktersebagai berikut:

1. Pengambil risiko moderat

2. Persuatif

3. Promotor

4. Kreatif

5. Mampu menghimpun sumber daya

6. Mampu mengambil inisiatif

7. Ulet

8. Mempunyai toleransi terhadap ambiguitas

9. Visioner

10. Optimis 
11. Penghubung

12. Bertumpu pada hasil

13. Pencari peluang

14. Percaya diri

15. Penentu

16. Enerjik

17. Mempunyai etika kerja yang kuat

18. Mempunyai atensi yang panjang

Ada beberapa faktor penting yang berperan dalam pembukaan usaha baru yaitu (Bygrave dalam Alma, 2018):

1. Environmental, berhubungan dengan lingkungan

2. Personal, berhubungan dengan aspek kepribadian seseorang

3. Sociological, berhubungan dengan keluarga

Jika seseorang mempunyai gagasan untuk membuka usaha maka akan memikirkan berbagai macam faktor yang dapat mendorong hal tersebut.Faktor pendorong ini tergantung pada berbagai macam faktor seperti keluarga, teman, pengalaman, kondisi ekonomi, kondisi lapangan kerja serta sumber daya yang ada.

Penelitian-penelitian

mengenaiberbagai macam faktor yang mempengaruhi seseorang untuk menjadi wirausahawan telah banyak dilakukan. Berdasarkan review literatur yang dilakukan oleh Kerr dan $\mathrm{Xu}$ terdapat ciri-ciri kepribadian seorang wirausaha yaitu kepercayaan diri akan kemampuannya untuk sukses dalam melakukan sesuatu, inovatif, kemampuan individu untuk mengontrol dirinya sendiri, dan kebutuhan akan pencapaian (Kerr, 2017). Mustapha dan Selvaraju meneliti tentang kepribadian individu, pengaruh keluarga, pendidikan kewirausahaan dan kecenderungan berwirausaha di antara mahasiswa universitas di Malaysia (Mustapha, 2015). Penelitian dilakukan dengan membagikan kuesioner pada mahasiswa Prodi Akuntansi di tiga perguruan tinggi negeri di Lembah KelangMalaysia. Hasil penelitian menunjukkan bahwa karakteristik individu, pendidikan kewirausahaan, dan keluarga berpengaruh positif terhadap minat mahasiswa berwirausaha. Namun gender tidak 
berpengaruh penting dalam mempengaruhi mahasiswa untuk juga memiliki peran penting dan berwirausaha. Penelitian yang menjadi panutan (Keat, 2011).

dilakukan oleh Purwanto menunjukkan bahwa ada perbedaan minat berwirausaha pada etniscina,jawa,dan arab namun minat untuk berwirausaha pada etnis cina,jawa, arab dan termasuk sedang. Minat berwirausaha menurut Hisrich (Hisrich, 2017) adalah faktor motivasi yang mempengaruhi seseorang untuk mengejar hasil dari kewirausahaan. Minat berwirausaha menurut Daryanto (Daryanto, 2013) dipengaruhi oleh faktor-faktor yang menyangkut kepribadian, faktor yang berhubungan dengan orang tua dan keluargafaktor yang berhubungan dengan teman, , serta faktor yang berhubungan dengan lingkungan.

Bisnis keluarga maupun bisnis yang dimiliki oleh teman sebaya diketahui menginspirasi lulusan yang baru lulus dari perguruan tinggi karena menyediakan lingkungan yang mendukung yaitu dengan memberikan informasi dan sumber daya untuk memulai bisnis setelah mereka lulus (Bagheri, 2010). Teman yang terlibat dalam kewirausahaan

\section{Kepribadian Wirausahawan}

Jika seseorang memiliki minat berwirausaha maka akan memiliki kepribadianyang percaya diri, mempunyai jiwa pemimpin,berani untuk mengambil resiko, inovatif serta mempunyai inisiatif. Kepribadian tersebut harus dimiliki oleh wirausahawan karena dalam mengelola bisnis memerlukan keberanian untuk menghadapi banyak hal seperti langkah-langkah yang akan ditempuh, cara menangani permasalahan usaha, cara mengelola karyawan agar usaha berkembang, dan lainnya. Seorang wirausahawan mempunyai kepribadian produktif (Alma, 2018). Pendidikan kewirausahaan yang diajarkan di perguruan tinggi belum tentu bisa mempengaruhi mahasiswa untuk menjadi seorang wirausahawan. Ada berbagai macam faktor yang bisa mempengaruhi seseorang untuk berwirausaha. Berdasarkan penelitian Chairy (2011), karakteristik wirausahawan 
mempengaruhi minat untuk berwirausaha. Karakteristik kepribadian wirausahawan terdiri dari (Gurol dan Atsan dalam Chairy, 2011):

1. Inovasi

2. Kebutuhan untuk berprestasi

3. Internal locus of control

4. Kecenderungan pengambilan risiko

5. Toleransi ambiguitas

6. Percaya diri

Ciri-ciri kewirausahaan terdiri dari aspek kepribadian yaitu watak, jiwa,perilaku,dan sikapseseorang (Suryana, 2013). Ciri-ciri kewirausahaan berdasarkan kepribadian terdiri dari:

1. Memiliki inisiatif

2. Penuh percaya diri

3. Memiliki jiwa kepemimpinan

4. Berani mengambil risiko dengan penuh perhitungan

5. Memiliki motif berprestasi

Karakteristik kepribadian wirausahawan berdasarkan Meredith dalam Suryana (2013) adalah:

1. Berani mengambil risiko dan menyukai tantangan

2. Percaya diri dan optimis
3. Berorientasi pada tugas dan hasil

4. Berorientasi masa depan

5. Kepemimpinan

6. Keorisinalitasan

Karakteristik kepribadian seorang wirausahawan adalah (Basrowi, 2011):

1. Berorientasi pada tugas dan hasil

2. Percaya diri

3. Berorientasi pada masa depan

4. Pengambilan risiko

5. Keorisinilan

6. Kepemimpinan

Pengaruh Lingkungan Keluarga terhadap Minat Berwirausaha

Keluarga, teman,, pasangan maupun pengusaha sukses yang menjadi idola bisa menjadirole modelyang mempengaruhi minat seseorang untuk menjadi wirausahawan (Alma, 2018). Teman, keluarga, maupun sahabat bisa mendorong seseorang untuk berwirausaha karena bisadiajak berdiskusi mengenai ideideberwirausaha, masalah yang dihadapi serta cara yang digunakan 
untuk menyelesaikan masalah tersebut. Pekerjaan orang tua jugaberpengaruh yaitu orang tua yang bekerja sendiri, dan memiliki usaha sendiri cenderung mempunyai anak yang menjadi pengusaha. Kewirausahaan identik dengan bisnis keluarga baik pada skala kecil maupun menengah dan besar. Oleh karena itu keluarga berperan aktif sebagai pihak yang mendukung dan mengembangkan bisnis keluarga. Berdasarkan penelitian yang dilakukan oleh Ariffin (2018), pekerjaan orang tua mempengaruhi minat berwirausaha mahasiswa FEB Universitas Lambung Amangkurat. Sedangkan penelitian yang dilakukan oleh Chairy (2011) menunjukkan bahwa tidak ada perbedaan minat berwirausaha pada mahasiswa yang orang tuanya berprofesi sebagai wirausahawan maupun yang berprofesi bukan sebagai wirausahawan

Pengaruh Gender terhadap Minat Berwirausaha

Berdasarkan penelitian Zimmerer dan Scarborough (Alma,
2018), perempuan yang berprofesi menjadi pengusaha berkembang dengan cepat di Amerika terutama padagolonganusaha kecil. Berdasarkan data Global Entrepreneurship Monitor (GEM) terdapat seratus dua puluh enam juta perempuan yang memulai atau menjalankan bisnis dan sembilan puluh delapan juta perempuan mengoperasikan bisnis yang sudah didirikan lebih dari tiga setengah tahun (GEM, 2016). Ada perbedaan antara pengusaha pria dan pengusaha wanita dalam membuka bisnis yaitu (Alma 2018):

1. Motif ingin berprestasi serta karena frustasi dengan pekerjaan sebelumnya

2. Pengusaha wanita mempunyai kepribadian yang fleksibel, toleran realistis, kreatif, antusias, enerjik sertamampu berhubungan dengan masyarakat. Tingkat kepercayaan diri pengusaha wanita berada pada level medium sedangkan pengusaha pria mempunyai kepercayaan diri tinggi 
3. Pengusaha pria lebih mudah untuk

mendapatkanpermodalan sedangkan pengusaha wanita agak susah untuk mendapatkanpermodalan

4. Pengusaha pria mebuka bisnis yang lebih beragam sedangkan

kebanyakanpengusaha wanita membuka bisnis yang berhubungan dengan jasa, konsultan, pendidikan, dan dan relasi publik

5. Pengusaha pria memulai usaha umumnya pada umur dua puluh lima sampai tiga puluh lima tahun sedangkan pengusaha wanita pada umur tiga puluh lima sampai empat puluh lima tahun

Menurut Yuhendri (2015), terdapat perbedaan minat berwirausaha antara mahasiswa laki-laki dan perempuan di Fakultas Ekonomi Universitas Negeri Padang. Minat mahasiswa laki-laki untuk berwirausaha lebih tinggi dibandingkan minat mahasiswa perempuan. Penelitian yang dilakukan oleh Yulinasari
(2016) menunjukkan bahwa tidak ada perbedaan antara minat berwirausaha mahasiswa laki-laki dan mahasiswa perempuan di Prodi Manajemen universitas Diponegoro. Berdasarkan Herington (dalam Farrington, 2012), terdapat kecenderungan bahwa perempuan mempunyai minat berwirausaha yang lebih rendah dibandingkan dengan laki-laki di Afrika Selatan

\section{Pengaruh Etnis terhadap Minat Berwirausaha}

Berdasarkan penelitian yang dilakukan oleh Ariffin (2018), terdapat pengaruh dari asal etnis terhadap minat berwirausaha mahasiswa Fakultas Ekonomi dan Bisnis Universitas Lambung Amangkurat. Sedangkan berdasarkan penelitian yang dilakukan oleh Chairy (2011) menunjukkan bahwa tidak terdapat perbedaan antara asal etnis terhadap minat berwirausaha mahasiswa program sarjana di Jakarta. Menurut Farrington (2012), variable demografis yaitu asal etnis, tingkat Pendidikan dan asal universitas mempunyai pengaruh yang signifikan terhadap minat 
mahasiswa untuk mendirikan usaha sendiri.

\section{Pengaruh Teman Sebaya terhadap} Minat Berwirausaha

Hubungan pertemanan dengan teman sebaya dibangun oleh kesamaan minat (Baron, 2012). Memiliki teman memberi pengaruh positif sebab teman dapat mendorong self-esteem dan menolong dalam

\section{METODOLOGI PENELITIAN}

\section{Lokasi Penelitian}

Penelitian ini dilakukan pada mahasiswa Fakultas Ekonomi dan Sosial Universitas Jenderal Achmad Yani Yogyakarta (FES UNJAYA). FES UNJAYA mempunyai empat program studi yaitu Manajemen (S1), Akuntansi (S1), Hukum (S1) dan Psikologi (S1). FES UNJAYA baru berdiri pada tahun 2018 sehingga pada tahun 2018 baru mempunyai satu angkatan yaitu mahasiswa angkatan 2018. Dari empat prodi tersebut ada tiga prodi yang mengajarkan mata kuliah kewirausahaan yaitu Prodi situasi stress tetapi teman juga memiliki efek negatif jika mereka antisosial, menarik diri, tidak suportif, argumentatif, atau tidak stabil. Berdasarkan penelitian Artanova (2018), pergaulan teman sebaya memberikan pengaruh positif terhadap minat berwirausaha mahasiswa Program Studi Pendidikan Akuntansi Universitas Muhammadiyah Surakarta.

Manajemen, ProdiAkuntansi dan ProdiPsikologi. Sedangkan Program Studi Hukum tidak menyelenggarakan mata kuliah kewirausahaa namun mengajarkan mata kuliah Keadvokatan. Populasi penelitian ini adalah seluruh mahasiswa semester dua FES UNJAYA dari empat program studi yaitu Manajemen (S1), Akuntansi (S1), Hukum (S1) dan Psikologi (S1). Jumlah populasi mahasiswa FES UNJAYA adalah 137 orang. Mahasiswa Program Studi Manajemen terdiri dari tiga puluh 
lima orang, mahasiswa Program Studi Akuntansi terdiri dari tiga puluh satu orang, mahasiswa Program Studi Hukum terdiri dari dua puluh tiga orang dan mahasiswa Program Studi Psikologi terdiri dari empat puluh enam orang

\section{Variabel Penelitian}

Penelitian ini menggunakan kuesioner tertutup dengan menggunakan skala Likert untuk mengukur minat berwirausaha mahasiswa. Kuesioner ini berisi pertanyaan dan pilihan jawaban sehingga mahasiswa dapat memilih salah satu jawaban yang tersedia.Jawaban Pertanyaan terdiri dari lima pilihan yaitu Sangat Setuju (SS), Setuju (S), Netral (N), Tidak Setuju (TS), dan Sangat Tidak Setuju
(STS). Variabel independen pada penelitian ini adalah kepribadian, etnis, lingkungan keluarga, gender, danteman sebaya. Sedangkan variabel dependen (Y) dalam penelitian ini adalah minat berwirausaha.

\section{Model Penelitian}

Model yang dikembangkan dalam penelitian ini merupakan pengembangan dari penelitian sebelumnya yang berjudul "Pengaruh Kepribadian, Lingkungan Keluarga, dan Teman sebaya terhadap minat berwirausaha mahasiswa Program Studi Pendidikan Akuntansi Fakultas Ekonomi Universitas negeri Yogyakarta oleh Siti Nafi' ahNurhadifah.

\section{Gambar 3.1 Model Penelitian}

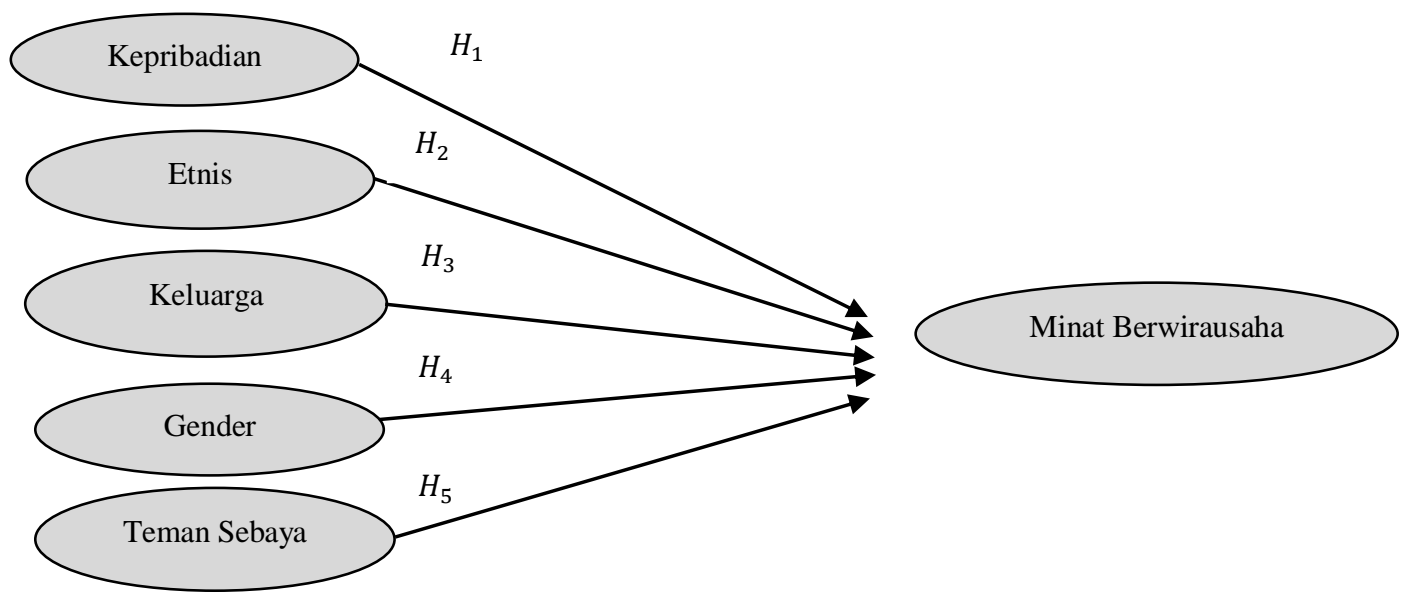




\section{Teknik Pengumpulan Data}

Penelitian ini menggunakan metode purposive sampling untuk mengumpulkan data primer dalam bentuk kuesioner. Peneliti menyebarkan kuesioner pada responden dengan yang berasal dari prodi manajemen, prodi akuntansi, prodi hukum dan prodi psikologi. Responden akan ditanyakan mengenai kesedian berpartisipasi dalam penelitian ini dengan mengisi kuesioner.

Data yang telah terkumpul dari kuesioner yang disebarkan selanjutnya dianalisis menggunakan analisis statistik. Analisis statistik yang dilakukan terdiri dari uji linearitas, uji multikolinearitas, uji heteroskedasitas dan regresi 


\begin{tabular}{|c|c|c|c|}
\hline Variabel & Definisi & Indikator & Skala Pengukuran \\
\hline $\begin{array}{l}\text { Minat } \\
\text { berwirausaha }\end{array}$ & $\begin{array}{lr}\text { Kecenderungan mahasiswa } \\
\text { untuk menjadi } \\
\text { wirausahawan }\end{array}$ & $\begin{array}{l}\text { - Saya akan memilih karir sebagai } \\
\text { wirausahawan } \\
\text { - } \quad \text { Saya akan memilih karir sebagai } \\
\text { pegawai/karyawan } \\
\text { - } \quad \text { Saya lebih menyukai menjadi } \\
\text { seorang wirausahawan } \\
\text { dibandingkan menjadi karyawan }\end{array}$ & $\begin{array}{l}\text { Skala likert } 5 \text { point } \\
1=\text { sangat tidak setuju } \\
5=\text { Sangat setuju }\end{array}$ \\
\hline Kepribadian & $\begin{array}{l}\text { Karakteristik kepribadian } \\
\text { mahasiswa }\end{array}$ & $\begin{array}{ll}- & \text { Pantang menyerah } \\
\text { - } & \text { Percaya diri } \\
\text { - } & \text { Mau mengambil risiko } \\
\text { - } & \text { Berorientasi pada tugas dan hasil } \\
\text { - } & \text { Inovatif } \\
\text { - } & \text { Berorientasi pada masa depan } \\
\end{array}$ & $\begin{array}{l}\text { Skala likert } 5 \text { point } \\
1 \text { = sangat tidak setuju } \\
5=\text { Sangat setuju }\end{array}$ \\
\hline Etnis & $\begin{array}{l}\text { Latar belakang etnis } \\
\text { mahasiswa }\end{array}$ & $\begin{array}{ll}\text { - } & \text { Menghadapi situasi yang } \\
\text { menantang } & \\
\text { - } & \text { Berjuang mengatasi situasi yang } \\
\text { tidak stabil } \\
\text { - } & \text { Mengambil keputusan } \\
\end{array}$ & \begin{tabular}{ll}
\multicolumn{2}{l}{ Kategorikal } \\
1. & Jawa \\
2. & Padang \\
3. & Batak \\
4. & Lainnya \\
\end{tabular} \\
\hline $\begin{array}{l}\text { Lingkungan } \\
\text { keluarga }\end{array}$ & $\begin{array}{l}\text { Pengaruh orang tua } \\
\text { mahasiswa terhadap minat } \\
\text { berwirausaha mahasiswa }\end{array}$ & $\begin{array}{l}\text { Kategori etnis yang mayoritas } \\
\text { memiliki profesi wirausahawan }\end{array}$ & $\begin{array}{ll}\text { Kategorikal } \\
\text { 1. Wirausahawan } \\
\text { 2. Non } \\
\\
\text { wirausahawan } \\
\end{array}$ \\
\hline Gender & Jenis gender mahasiswa & & $\begin{array}{l}\text { Kategorikal } \\
\text { 1. Laki-laki } \\
\text { 2. } \\
\text { Perempuan }\end{array}$ \\
\hline Teman sebaya & $\begin{array}{l}\text { Teman yang mendukung } \\
\text { mahasiswa untuk menjadi } \\
\text { seorang wirausahawan }\end{array}$ & 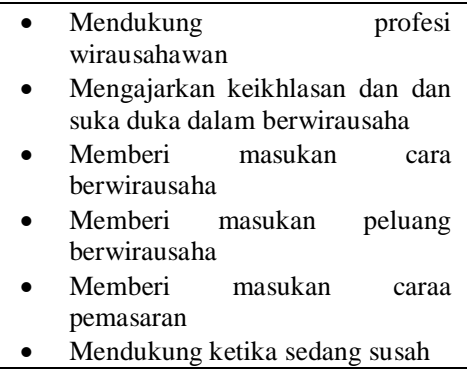 & $\begin{array}{l}\text { Skala likert } 5 \text { point } \\
1 \text { = sangat tidak setuju } \\
5 \text { = Sangat setuju }\end{array}$ \\
\hline
\end{tabular}

Tabel 3.1 Variabel, Definisi, Indikator dan Skala Pengukuran

\section{HASIL DAN PEMBAHASAN}

Uji asumsi klasik dilakukan dengan tujuan untuk mengetahui adanya multikolinearitas, heteroskedastisitas dan normalitas.Hasil uji asumsi klasik terhadap variabel independen dan variabel dependen menunjukkan bahwa tidak adamultikolinearitas, homoskesdasitisitas dan normalitas. Berdasarkan hasil pengujian terhadap delapan puluh delapan responden yang berasal dari empat program studi di FES UNJAYA didapatkan hasil sebagai berikut.

\section{Karakteristik Kepribadian}

Untuk mengetahui pengaruh kepribadian terhadap minat berwirausaha mahasiswa maka dilakukan uji F. Hasil uji F disajikan pada tabel 4.1 berikut ini. 
Tabel 4.1 Uji F untuk karakteristik kepribadian - Anova

\begin{tabular}{|ll|r|r|r|r|r|}
\hline \multicolumn{1}{|c|}{ ANOVA $^{\mathrm{a}}$} \\
\hline \multirow{3}{*}{1} & Sum of Squares & \multicolumn{1}{c|}{ df } & Mean Square & F & Sig. \\
\hline & Regression & 14.249 & 6 & 2.375 & 8.585 & $.000^{\circ}$ \\
& Residual & 22.406 & 81 & .277 & & \\
& Total & 36.655 & 87 & & & \\
\hline
\end{tabular}

a. Dependent Variable: Minat berwirausaha

b. Predictors: (Constant), Berorientasi masa depan, Pantang Menyerah, Mau Mengambil Resiko,

Percaya Diri, inovatif, Berorientasi tugas dan hasil

Nilai $F$ adalah 8,585 dengan angka $\begin{array}{lll}\text { signifikansi } & \text { sebesar } & 0.000\end{array}$ menunjukkan bahwa ada pengaruh kepribadian terhadap minat berwirausaha.Nilai $\mathrm{R}$ square pada tabel adalah sebesar 0,389 menunjukkan bahwa enam variabel kepribadian yang diteliti mampu menjelaskan minat berwirausaha sebesar $38,9 \%$ sedangkan sisanya dijelaskan oleh variabel lain yang tidak diteliti dalam penelitian ini.

Tabel 4.2 Nilai R Square - Model Summary

\begin{tabular}{|l|r|r|r|c|}
\hline Model & \multicolumn{1}{|c|}{ Model Summary } \\
\hline 1 & R Square & $\begin{array}{c}\text { Adjusted R } \\
\text { Square }\end{array}$ & $\begin{array}{c}\text { Std. Error of the } \\
\text { Estimate }\end{array}$ \\
\hline
\end{tabular}

a. Predictors: (Constant), Berorientasi masa depan, Pantang

Menyerah, Mau Mengambil Resiko, Percaya Diri, inovatif, Berorientasi tugas dan hasil

Untuk mengetahui pengaruh masingmasing dari keenam unsur kepribadian terhadap minat berwirausaha dilakukan Uji $\mathrm{T}$. Berdasarkan hasil uji $\mathrm{T}$ didapatkan hasil bahwa ada satu nilai $\mathrm{T}$ hitung yang lebih besar dari 1,98 yaitu berorientasi pada tugas dan hasil. Dengan demikian sifat pantang menyerah, percaya diri, mau mengambil risiko, inovatif dan berorientasi masa depan tidak mempengaruhi minat berwirausaha 
Tabel 4.3 Uji T-Coefficients

\begin{tabular}{|c|c|c|c|c|c|c|}
\hline \multicolumn{7}{|c|}{ Coefficients $^{\mathrm{a}}$} \\
\hline \multirow[t]{2}{*}{ Mod } & & \multicolumn{2}{|c|}{ Unstandardized Coefficients } & \multirow{2}{*}{$\begin{array}{c}\begin{array}{c}\text { Standardized } \\
\text { Coefficients }\end{array} \\
\text { Beta }\end{array}$} & \multirow[t]{2}{*}{$\mathrm{t}$} & \multirow[t]{2}{*}{ Sig. } \\
\hline & & B & Std. Error & & & \\
\hline \multirow{7}{*}{1} & (Constant) & 1.527 & .469 & & 3.255 & .002 \\
\hline & Pantang Menyerah & .034 & .056 & .054 & .600 & .550 \\
\hline & Percaya Diri & .144 & .098 & .162 & 1.474 & .144 \\
\hline & Mau Mengambil Resiko & -.007 & .114 & -.007 & -.063 & .950 \\
\hline & Berorientasi tugas dan hasil & .527 & .118 & .601 & 4.451 & .000 \\
\hline & inovatif & -.179 & .122 & -.182 & -1.471 & .145 \\
\hline & Berorientasi masa depan & .050 & .094 & .055 & .529 & .598 \\
\hline
\end{tabular}

Hal ini sejalan dengan hasil penelitian Putri (2018) yang menunjukkan bahwa kepribadian mempengaruhi minat berwirausaha mahasiswa warga muda di Kecamatan Kretek, Bantul, Yogyakarta. Berdasarkan penelitian

\section{Etnis}

Etnis yang diteliti dalam penelitian ini terdiri dari Jawa, Sunda, Batak, Melayu dan etnis lainnya. Jumlah responden berdasarkan asal etnis adalah Jawa (73), Melayu (6), Sunda (2), Batak
Nurhadifah (2018) menunjukkan bahwa kepribadian berpengaruh positif terhadap minat berwirausaha mahasiswa Program Pendidikan Akuntansi Universitas Negeri Yogyakarta.
(2), dan etnis lainnya (5). Etnis lainnya terdiri dari berbagai macam etnis yang yang jumlahnya sangat kecil sehingga disatukan. Skor minat berwirausaha berdasarkan asal etnis berkisar antara 1,7 sampai 5,9.

Tabel 4.1 Minat berwirausaha menurut etnis

Descriptives

\begin{tabular}{|c|c|c|c|c|c|c|c|c|}
\hline & \multirow[t]{2}{*}{$\mathrm{N}$} & \multirow[t]{2}{*}{ Mean } & \multirow[t]{2}{*}{ Std. Deviation } & \multirow[t]{2}{*}{ Std. Error } & \multicolumn{2}{|c|}{$95 \%$ Confidence Interval for Mean } & \multirow[t]{2}{*}{ Minimum } & \multirow[t]{2}{*}{ Maximum } \\
\hline & & & & & Lower Bound & Upper Bound & & \\
\hline Jawa & 73 & 3.7900 & .67702 & .07924 & 3.6320 & 3.9479 & 1.33 & 4.67 \\
\hline Sunda & 2 & 3.8333 & .23570 & .16667 & 1.7156 & 5.9510 & 3.67 & 4.00 \\
\hline Batak & 2 & 3.6667 & .00000 & .00000 & 3.6667 & 3.6667 & 3.67 & 3.67 \\
\hline Melayu & 6 & 4.3333 & .47140 & .19245 & 3.8386 & 4.8280 & 3.67 & 5.00 \\
\hline Lainnya & 5 & 3.7333 & .43461 & .19437 & 3.1937 & 4.2730 & 3.33 & 4.33 \\
\hline Total & 88 & 3.8220 & .64910 & .06919 & 3.6844 & 3.9595 & 1.33 & 5.00 \\
\hline
\end{tabular}


Untuk menguji ada atau tidaknya minat berwirausaha berdasarkan asal etnis maka dilakukan rata-rata dengan anova dengan hasil nilai $\mathrm{F}$ sebesar 1,029 dengan nilai signifikansi sebesar 0,397. Hal ini menunjukkan bahwa tidak ada perbedaan yang signifikan dalam minat berwirausaha antar etnis yang diteliti. Dengan demikian hipotesis yang menyatakan bahwa ada perbedaan minat berwirausaha antar etnis ditolak. Hal ini sejalan dengan penelitian Chairy yang menyatakan bahwa tidak ada perbedaan antar etnis dalam minat berwirausaha mahasiswa.

Tabel 4.2 Uji F untuk etnis - Anova

ANOVA

Minat berwirausaha
\begin{tabular}{|l|r|r|r|r|r|}
\hline & Sum of Squares & df & Mean Square & \multicolumn{1}{|c|}{ F } & Sig. \\
\hline Between Groups & 1.732 & 4 & .433 & 1.029 & .397 \\
Within Groups & 34.924 & 83 & .421 & & \\
Total & 36.655 & 87 & & & \\
\hline
\end{tabular}

\section{Lingkungan Keluarga}

Lingkungan keluarga merupakan lingkup terkecil yang akan membentuk masa depan anak. Berdasarkan data terdapat lima belas orang dari delapan puluh delapan orang tua mahasiswa atau $17,1 \%$ orang tua mahasiswa yang berprofesi sebagai wirausahawan. Untuk mengetahui pengaruh lingkungan keluarga terhadap minat berwirausaha mahasiswa maka dilakukan uji F. Hasil Uji F disajikan dalam tabel 4.6.

Tabel 4.3 Uji F Lingkungan Keluarga

\begin{tabular}{|c|c|c|c|c|c|c|}
\hline \multicolumn{7}{|c|}{ ANOVA ${ }^{a}$} \\
\hline & & Sum of Squares & df & Mean Square & $\mathrm{F}$ & Sig. \\
\hline \multirow{3}{*}{1} & Regression & 4.951 & 6 & .825 & 2.108 & $.061^{\mathrm{b}}$ \\
\hline & Residual & 31.704 & 81 & .391 & & \\
\hline & Total & 36.655 & 87 & & & \\
\hline
\end{tabular}

a. Dependent Variable: Minat berwirausaha

b. Predictors: (Constant), kel6, kel5, kel4, kel2, kel3, kel1 
Berdasarkan uji $\mathrm{F}$ didapatkan hasil Nilai $F$ adalah 2,108 dengan angka signifikansi sebesar $\quad 0.061$ menunjukkan bahwa tidak ada pengaruh lingkungan keluarga yaitu yang orang tuanya berprofesi sebagai wirausahawan maupun yang bukan wirausahawan terhadap minat

\section{Gender}

Berdasarkan data gender yang diperoleh dari mahasiswa responden penelitian, dua puluh dua orang (25\%) mahasiswa berjenis kelamin laki-laki dan enam puluh enam mahasiswa $(75 \%)$ berjenis kelamin perempuan. Berdasarkan berwirausaha. Hal ini sejalan dengan hasil penelitian Chairy (2011) yang menunjukkan bahwa tidak ada perbedaan minat berwirausaha mahasiswa yang orang tuanya berprofesi sebagai wirausahawan maupun bukan wirausahawan.

perhitungan didapatkan hasil minat berwirausaha sebesar 3,96 untuk laki-laki dan 3,77 untuk perempuan. Berdasarkan Uji T didapatkan hasil bahwa tidak ada perbedaan minat berwirausaha antara mahasiswa lakilaki dan perempuan.

Tabel 4.4 Uji T Gender

\begin{tabular}{|c|c|c|c|c|c|c|c|c|}
\hline \multicolumn{9}{|c|}{ Descriptives } \\
\hline \multicolumn{9}{|c|}{ Minat berwirausaha } \\
\hline & \multirow[t]{2}{*}{$\mathrm{N}$} & \multirow[t]{2}{*}{ Mean } & \multirow[t]{2}{*}{ Std. Deviation } & \multirow[t]{2}{*}{ Std. Error } & \multicolumn{2}{|c|}{$95 \%$ Confidence Interval for Mean } & \multirow[t]{2}{*}{ Minimum } & \multirow[t]{2}{*}{ Maximum } \\
\hline & & & & & Lower Bound & Upper Bound & & \\
\hline Laki-laki & 22 & 3.9697 & .48150 & .10266 & 3.7562 & 4.1832 & 3.33 & 4.67 \\
\hline Perempuan & 66 & 3.7727 & .69223 & .08521 & 3.6026 & 3.9429 & 1.33 & 5.00 \\
\hline Total & 88 & 3.8220 & .64910 & .06919 & 3.6844 & 3.9595 & 1.33 & 5.00 \\
\hline
\end{tabular}

Hal ini sejalan dengan penelitian Chairy yang menunjukkan bahwa tidak ada perbedaan minat berwirausaha antara mahasiswa lakilaki dan mahasiswa perempuan. 
Tabel 4.5 Uji F Gender

ANOVA

\begin{tabular}{|l|r|r|r|r|r|}
\hline & Minat berwirausaha \\
\hline & Sum of Squares & df & Mean Square & \multicolumn{1}{c|}{ F } & Sig. \\
\hline Between Groups & .640 & 1 & .640 & 1.529 & .220 \\
Within Groups & 36.015 & 86 & .419 & & \\
Total & 36.655 & 87 & & & \\
\hline
\end{tabular}

\section{Teman Sebaya}

Untuk mengetahui pengaruh teman sebaya terhadap minat berwirausaha mahasiswa maka dilakukan uji $\mathrm{F}$. Hasil uji $F$ disajikan pada tabel berikut ini.

Tabel 4.6 Uji F Teman Sebaya

\begin{tabular}{|c|c|c|c|c|c|c|}
\hline \multicolumn{7}{|c|}{ ANOVA ${ }^{a}$} \\
\hline & & Sum of Squares & $\mathrm{df}$ & Mean Square & $\mathrm{F}$ & Sig. \\
\hline \multirow{3}{*}{1} & Regression & 9.471 & 6 & 1.578 & 4.703 & $.000^{\circ}$ \\
\hline & Residual & 27.184 & 81 & .336 & & \\
\hline & Total & 36.655 & 87 & & & \\
\hline
\end{tabular}

a. Dependent Variable: Minat berwirausaha

b. Predictors: (Constant), ts 6 , ts 5 , ts $2, \mathrm{ts} 3, \mathrm{ts} 1$, ts 4

Nilai $F$ adalah 4,703 dengan angka $\begin{array}{lll}\text { signifikansi } & \text { sebesar } & 0.000\end{array}$ menunjukkan bahwa ada pengaruh teman sebaya terhadap minat berwirausaha. Nilai $\mathrm{R}$ square pada tabel sebesar 0,258 menunjukkan bahwa enam variabel teman sebaya yang diteliti mampu menjelaskan minat berwirausaha sebesar $25,8 \%$ sedangkan sisanya dijelaskan oleh variabel lain yang tidak diteliti dalam penelitian ini.

Tabel 4.7 Uji R teman Sebaya

\begin{tabular}{|l|r|r|r|r|}
\hline Model & \multicolumn{1}{|c|}{ Model Summary } \\
\hline 1 & R Square & $\begin{array}{c}\text { Adjusted R } \\
\text { Square }\end{array}$ & $\begin{array}{c}\text { Std. Error of the } \\
\text { Estimate }\end{array}$ \\
\hline
\end{tabular}

a. Predictors: (Constant), ts6, ts5, ts2, ts 3, ts 1, ts 4

Untuk mengetahui pengaruh masing-

masing dari keenam unsur pengaruh 
teman sebaya terhadap minat memberi masukan cara berwirausaha berwirausaha dilakukan Uji T. yang baik, memberi masukan tentang Berdasarkan hasil uji $\mathrm{T}$ didapatkan peluang berwirausaha, memberi tahu hasil bahwa ada satu nilai $\mathrm{T}$ hitung tentang cara pemasaran yang baik, yang lebih besar dari 1,98 yaitu mendukung ketika sedang susah teman mendukung mahasiswa tidak memberi pengaruh dalam minat menjadi wirausahawan. Dengan berwirausaha.

demikian mengajarkan keikhlasan

dan suka duka dalam berwirausaha,

Tabel 4.8 Uji T Teman Sebaya

\begin{tabular}{|c|c|c|c|c|c|c|}
\hline \multirow{2}{*}{\multicolumn{2}{|c|}{ Model }} & \multicolumn{3}{|c|}{ Coefficients $^{a}$} & \multirow{3}{*}{$\mathrm{t}$} & \multirow{3}{*}{ Sig. } \\
\hline & & \multicolumn{2}{|c|}{ Unstandardized Coefficients } & \multirow{2}{*}{$\begin{array}{c}\text { Standardized } \\
\text { Coefficients } \\
\text { Beta }\end{array}$} & & \\
\hline & & B & Std. Error & & & \\
\hline & (Constant) & 2.315 & .381 & & 6.070 & .000 \\
\hline & ts 1 & .361 & .122 & .471 & 2.950 & .004 \\
\hline & ts2 & -.222 & .129 & -.280 & -1.716 & .090 \\
\hline 1 & ts 3 & .208 & .118 & .289 & 1.766 & .081 \\
\hline & ts 4 & -.059 & .133 & -.078 & -.441 & .660 \\
\hline & ts5 & -.013 & .113 & -.018 & -.120 & .905 \\
\hline & ts 6 & .109 & .101 & .131 & 1.080 & .283 \\
\hline
\end{tabular}

a. Dependent Variable: Minat berwirausaha

\section{SIMPULAN}

Berdasarkan penelitian yang telah dilakukan diperoleh kesimpulan sebagai berikut:

1. Keluarga tidak berpengaruh pada minat berwirausaha mahasiswa Fakultas Ekonomi dan Sosial universitas Jenderal Achmad Yani Yogyakarta
2. Etnis tidak berpengaruh pada minat berwirausaha mahasiswa Fakultas Ekonomi dan Sosial universitas Jenderal Achmad Yani Yogyakarta

3. Kepribadian berpengaruh pada minat berwirausaha mahasiswa Fakultas Ekonomi dan Sosial universitas Jenderal Achmad Yani Yogyakarta 
4. Gender tidak berpengaruh pada minat berwirausaha mahasiswa Fakultas Ekonomi dan Sosial universitas Jenderal Achmad Yani Yogyakarta.

5. Teman sebaya berpengaruh pada minat berwirausaha mahasiswa Fakultas Ekonomi dan Sosial universitas Jenderal Achmad Yani Yogyakarta

Penelitian yang dilakukan ini masih

\section{DAFTAR PUSTAKA}

Alma, Buchari. (2013).

Kewiraushaan

untuk

Mahasiswa dan Umum. Edisi Revisi. Bandung : CV Alfabeta

Badan Pusat Statistik. (2019).

"Pengangguran Terbuka Menurut Pendidikan Tertinggi yang Ditamatkan 1986-2018". Diakses dari www.bps.go.id pada $25 \mathrm{Mei}$ 2019

Basrowi. (2011). Kewirausahaan untuk Perguruan Tinggi. Bogor : Ghalia Indonesia banyak kekurangan. Oleh karena itu penelitian ini dapat dikembangkan lebih lanjut supaya perguruan tinggi bisa memetakan faktor-faktor yang mempengaruhi minat mahasiswa untuk berwirausaha sehingga perguruan tinggi bisa merancang pembelajaran kewirausahaan yang tepat. Dengan merancang pembelajaran kewirausahaan yang tepat maka perguruan tinggi bisa mencetak wirausahawanwirausahawan baru.

Daryanto. (2013). Pengantar Kewirausahaan. Jakarta : Prestasi Pustakaraya

Husna, Arifatul Mohd Arif, Zainul Bidin, Zakiyah Syarif, Adura Ahmad. (2010). Predicting Entrepreneurial Intention Among Malay University Accounting Students in Malaysia. University Tun Abdul Razak e-journal 6(1): 1-10. Diakses dari http://ejournal.unirazak.edu. my/articles/predicting_entrep reneur_p1v61jan10.pdf pada 28 Mei 2019

Kemenristekdikti. (2018). Pacu pertumbuhan Wirausaha 


\begin{tabular}{lrr} 
Muda & \multicolumn{2}{c}{ Kemenristekdikti } \\
Berikan & Ijin & Perguruan \\
Tinggi & Kewirausahaan \\
Pertama & di & Indonesia. \\
Diakses & \multicolumn{3}{c}{ dari } \\
https://www.ristekdikti.go.id \\
pada 27 mei 2019
\end{tabular}

Kulgasaran, P. (2010). Building on Business and Soft Skills. Diakses dari http://thestar.com.my/educati on/story.asp?sec=education \&file $=/ 2010 / 12 / 5 /$ education/ 7366750/ pada 28 Mei 2019

Suhartini, Yati. (2011). Analisis

Faktor-faktor yang

Mempengaruhi Minat

Mahasiswa dalam

Berwirausaha. Jurnal

Akmenika UPY, Vol. 7, 2011.

The Global Entrepreneurship Index and Development Institute. (2019). "2018 Global Entrepreneurship Index Rankings. Diakses dari www.thegedi.org pada 26 Mei 2019

Weber, Richard. (2011). Evaluating Entrepreneurship Education. Munich: Springer Gabler

Westhead, Paul, Mike Wright. (2013). Entrepreneurship: A Very Short Introduction. Oxford: Oxford University Press 